\title{
The Adoption of Found Child According to Islamic Law and Law No. 3 of 2006 on Religious Courts in the Perspective of Maqasid Al-Shari'ah
}

\section{Siti Muniroh}

Pengadilan Tinggi Agama Yogyakarta, Yogyakarta, Indonesia Email: sitimunirohbasrowi@gmail.com

Khoiruddin Nasution

Universitas Islam Negeri Sunan Kalijaga, Yogyakarta, Indonesia

Article History:

\begin{tabular}{|l|l|}
\hline Received: Februari 15, 2021 & Accepted: Agustus 13, 2021 \\
\hline Revised: April 09, 2021 & \\
\hline
\end{tabular}

\section{Abstract}

Islam is a religion that regulates everything in the life of Muslims. No exception in the case of adoption, the jurisdiction of the court up to the adoption of a minor. in the case of child adoption. Today, Islam applies limitations in some matters, such as the prohibition of lineage, the establishment of non-mahram relationships to the issue of inheritance and guardianship. In addition to that field, there is the authority of the judge in the Religious Court to be ijtihad to determine the best decision for the child of the findings as the extent of its authority is based on Law No. 3 of 2006 on Religious Justice. The purpose of this study is to analyze how the legal impact on the adoption status of the findings based on the rationale maqasidus syar'i and its relevance to the development of Islamic law. Research methods use the study of literature through its sources of reference through primary law, both derived from religious sources and from positive legal sources that apply in Indonesia. In addition, the researcher used jurisprudence from the relevant judicial decisions used.The results of this research are (1) through the approach of maqasid al shari'ah doruriyah that 
children (including children of discovery) must be protected their rights, both their right to life (an nafs) and their intellect (al aql), the right of lineage, religion, as well as paying attention to his rights, including his right to obtain the obligatory will/right of inheritance from the parents who raised him (al maal), (2) The legal impact is, the child is found as a person, he is an orphan so the religious treatment is the same as an orphan. While the adopted child then the legal status can be assessed through recognition by the adoptive parents such as the child of guardianship, then the adopted child has the right to be guarded by his adoptive parents due to the absence of a lineage guardian. (3) While the relevance to the development of Islamic law is that in maintenance (other than the issue of lineage and inheritance), then the child has the same protection and education status of both adoptive parents. There is a need for efforts from various related parties to prioritize the benefits to protect from unwanted things and save the lives of children.

\section{Keywords: Adopted Child, Laqit, Guardian, Maqasid al Syari'ah}

\section{Abstrak}

Islam merupakan agama yang mengatur segala hal dalam kehidupan ummat Islam. Tidak terkecuali dalam hal pengangkatan anak, wewenang pengadilan sampai pada pengangkatan anak laqit. dalam hal pengangkatan anak. Pada dewasa ini Islam menerapkan batasan-batasan di beberapa hal, seperti pelarangan pengaitan nasab, penetapan hubungan bukan mahram sampai pada masalah warisan dan perwalian. Selain bidang itu, maka terdapat wewenang hakim pada Pengadilan Agama untuk berijtihad menetapkan putusan yang terbaik bagi anak temuan sebagaimana keluasan wewenangnya berdasarkan pada Undang-undang Nomor 3 Tahun 2006 Tentang Peradilan Agama. Tujuan penelitian ini adalah untuk menganalisis bagaimana dampak hukum terhadap status pengangkatan anak temuan berdasarkan nalar maqasidus syar'i serta relevansinya terhadap pengembangan hukum Islam. Metode penelitian menggunakan studi literatur melalui sumber rujukannya lewat hukum primer, baik yang diasalkan dari sumber agama maupun dari sumber hukum positif yang berlaku di Indonesia. Selain itu peneliti menggunakan yurisprudensi dari putusan-putusan hakim 
yang relevan digunakan. Hasil penelitian ini adalah (1) melalui pendekatan maqasid al syari'ah doruriyah bahwa anak-anak (termasuk anak temuan) harus dilindungi hak-haknya, baik hak kehidupannya (an nafs) maupun akal pikiran nya (al aql), hak nasab, agama, serta memperhatikan hak-haknya termasuk dalam hak nya memperoleh wasiat wajibah/hak waris dari orangtua yang mengangkatnya (al maal), (2) Dampak hukumnya adalah, anak temuan sebagai person, ia adalah anak yatim sehingga perlakuan secara agama sama seperti anak yatim. Sedangkan anak temuan yang diangkat maka status hukumnya dapat dinasabkan melalui pengakuan oleh orang tua angkatnya seperti anak hal perwalian, maka anak angkat berhak diwalikan oleh orangtua angkatnya karena ketiadaan wali nasab. (3) Sedangkan relevansinya terhadap pengembangan hukum Islam adalah bahwa dalam pemeliharaan (selain masalah nasab dan pewarisan), maka anak mempunyai status pengayoman dan pendidikan yang sama dari kedua orangtua angkatnya. Perlu adanya upaya dari berbagai pihak yang terkait untuk mengutamakan kemaslahatan untuk melindungi dari hal-hal yang tidak diinginkan dan menyelamatkan kehidupan anak temuan.

Kata kunci: Anak Angkat, Laqit, Wali, Maqasid al Syari'ah 


\section{INTRODUCTION}

Child adoption is a very important discourse to academicians and needs to be studied comprehensively. As legal objects, children are highly vulnerable parties after obtaining legal certainty from the adoption determination. Adopted children may face various vulnerabilities, including welfare and psychological health insurance, and human trafficking.

The number of neglected Indonesian children is fast-growing, which may cause social insecurities. In 2015, data from the Ministry of Social Affairs showed that 5,900, 3,600, 1.2 million, and 34,000 children are objects of human trafficking, involved in legal problems, neglected, and live on the streets, respectively.

According to Article 49, Law No. 3 of 2006 replaces Law No. 7 of 1989 on the Religious Courts and provides legal certainty for Indonesian child adoption. The Law No. 3 of 2006 states that:

"The Religious Court has the Duty and Authority to examine, decide, and settle cases at the first level between people who are Muslim in the field of a. marriage. Explanation of Letter ' $a$ ' in Article 49 states that "what is meant by marriage are matters regulated in or based on the applicable marriage law, carried out according to sharia, such as Determination of Origin and Determination of Child Adoption based on Islamic law."

The enactment of the law results from legal changes meant to fulfill the needs of the community. The Religious Courts have complete authority from the Indonesian legislators to handle child adoption under Islamic Law. However, field practice faces various problems, including the different adoptions recommended in Islam

1 Priyambodo, "Mensos: Masih Banyak Kasus Anak Terlantar," News, Antara News, 2015, https://www.antaranews.com/berita/496359/mensos-masihbanyak-kasus-anak-terlantar. 
and their legal impacts on the child, father, mother, and adoptive brother, among other related matters. ${ }^{2}$

As legal objects, children are highly vulnerable parties. In protection efforts of parenting and legal rights, the Government Regulation No. 44 of 2017 focuses on maintaining their legal protection. However, the discussion about parents adopting a child from an Islamic perspective faces complex problems. The Encyclopedia of Islamic Law defines 'a child' as 'a boy or girl born from a mother's womb as a result of a relationship between two genders.' Etymologically in Arabic, the term 'child' originates from the word 'walād' whose plural form is 'awlād,' meaning 'a boy or girl, big or small, and born from both parents.' Still, another opinion defines a 'child' as 'a human who is still small and immature.' Maturity in boys and girls is marked by wet dreams and menstruation, respectively. ${ }^{3}$

Various rights related to children include nasab (lineage), breastfeeding (radla), maintenance (hadhonah), and living support and guardianship regarding protection (walayah). ${ }^{4}$ When parents abandon their children, these rights are interfered with. Adoption becomes the appropriate instrument to protect their rights, including daruriyah or dharuri issues. According to Islamic Law, maqasid al shari'ah explains the purpose for the existence of the law to benefit humanity in its entirety. Therefore, the concept of maqasid al shari'ah, whose substance is a benefit, helps establish law and develop Islamic

2 Rifyal Ka'bah, "'Pengangkatan Anak Dalam UU No. 3 Tahun 2006 Tentang Perubahan Atas UU No. 7 Tahun 1989 Tentang Peradilan Agama Dan Akibat Hukumnya' Makalah Dikembangkan Dari Diskusi Berkala III Di Bidang Pencatatan Sipil Antara Para Ahli Hukum Islam Dan Hukum Sekuler," 2006.

${ }^{3}$ Dahlan Abdul Azis, Ensiklopedi Islam (Jakarta: PT Ichtiar Baru Van Hoeve, 1980), 177.

4 Ahmad al-Ghandûr, Al-Akhwâl al-Syakhshiyah Fi al-Tasyri al-Islâmî (Beirut: Maktabah al-Falah, 2006), 596-637. 
Law to answer contemporary problems, especially those not controlled by the Qur'an and as-sunnah.

Wahbah Zuhaili stated that 'maqasid al shari'ah is an order of values and objectives of syara' contained in all or the majority of its laws.' For every legal provision, the order of values and objectives is considered as the targets and secrets of sharia determined by al-syari' in every legal provision. ${ }^{5}$ Furthermore, Yusuf Al-Qardhawi stated that 'the target of the existence of texts and particular laws to be realized in human life is maqasid al-shari'ah.' These laws come in various forms, including orders, prohibitions, and permissibility for individuals, families, groups, and people. ${ }^{6}$

To develop the Islamic legal thought in its entirety and solve contemporary problems, Maqasid shari'ah is critical for mujtahids. This applies especially to problems the Qur'an and Sunnah, which are the main sources of Islam, do not regulate. There is a need to appreciate the application of a legal provision. When changes occur in social conditions, a certain law can be invalidated. ${ }^{7}$ Since its construction took place in the early days during the Middle Ages, the study of maqâshidal-syarị'ah by experts in Islamic Law has always shown development. The urgency of maqāsid shari'ah in ijtihad makes a person have at least two criteria, including a complete understanding of maqāsid shari'ah and the ability to reveal the weight of law based on knowledge and comprehension of maqāsid shari'ah, Arabic, Qur'an, and the hadith.

Since every problem human face focuses on a certain legal basis, knowing and understanding maqasid shari'ah is critical in

\footnotetext{
${ }^{7}$ Moh. Mukri, Paradigma Maslahah Dalam Pemikiran Al Gahzali Sebuah Studi Aplikasi Dan Implikasi Terhadap Hukum Islam Kontemporer (Yogyakarta: Pesantren Nawasea Press, 2009), 91.
} 12.

${ }^{5}$ Wahbah Zuhaili, Ushul Fiqh Islamy, 2 (Damaskus: Dar al Fikr, 1986), 748.

${ }^{6}$ Yusuf Qardhawi, Fikih Maqasid Syari'ah (Jakarta: Pustaka Al-Kautsar, 2007), 
conducting ijtihād. Such a foundation is the key to the success of a mujtahid in conducting ijtihad. It is not about seeing the problem as a new thing and literally not regulated in the texts, nor finding out whether a legal provision can be applied to a particular case or not when values shift due to social change. Rather, the essence of the maqasid shari'ah concept is a benefit. According to Qayyim al-Jauziyah, 'maqâshid al-sharị'ah preventts chaos in the world and creates benefit for mankind, controls the world with virtue, justice and goodness, and clarifies the signs of the path the human mind should take. ${ }^{8}$

Adopting a found child and its legal consequences has been studied frequently, and it has been discussed in religious texts. However, this does not mean that the study has stopped considering that the dynamics of social life are developing very rapidly. Regarding Islamic Law and its consequences, Ibrahim Hosen stated that 'several principal things need to be considered, especially qath' $i$ law created from qath'i texts.' Since this law should deny a legal provision based on mutawatir and all kinds of ikhtimal (probability) forms to make a text qath'I, it has limits, and it can be counted in numbers. For example, the text lacks ihtimal majaz, kinayah, idhmar, takhsis, taqdim, ta'khir, naskh, or ta'arud al aqli. Therefore, even though there are claims that when something is lafadz nash, it contains ihtimal, it is still considered dzanny. Furthermore, the text has been made into qath'i, the qath'i fi jami' al ahwal, or fi ba'd al ahwal. In case it is fi jami 'al ahwal, the rule of "laa ijtihada fi muqabalat al nash" applies. However, suppose the qath' $i$ is fi ba'd al ahwal; it can be fighkan. Thus, based on this opinion, Ibrahim Hosen explained that 'there are two categories in Islamic law, the original one (azimah) and the other that violates the first one due to a change in the atmosphere (rukhsah).'

8 Ibn al-Qayyim al-Jauziyah, I'lām al- Muwaqqi'in, 3 (Kairo: Daarul Al-Kutub Al-Hadis, 1969), 177.

9 Juhaya S. Praja, Teori Hukum Dan Aplikasinya (Bandung: Pustaka Setia, 1994), 87. 
Several journals have discussed the concept of a found child (laqith) and the mandatory wills, which serve as solutions to the problem of inheriting him outside a marriage. According to Abdul Rokhim, in Islamic Law, 'a found child can be assigned to whoever finds him through recognition.' With this, he becomes legitimate and biological. Besides, whoever finds and recognizes the found child can also be a guardian in marriage when the child is ready for it. According to Mahmud Shaltut, 'adopting a child is asking other people's child for care and education, pouring love with all heart, treating her as his own, and without giving the status of a biological child. Still, according to another version, adopting a child is 'asking or taking another person's child and giving him the status of a biological child. This means that he has the right to belong to his adoptive parents and have inheritance and other rights as the relationship between a child and the parents. ${ }^{10}$

The Islamic Law has given careful consideration to adoption institutions, especially to the found child called 'laqith.' This is the same as the Muslim Family Law in the Middle East Islamic State, which requires Muslims to support and provide protection for the found child as they are all obliged. When a Muslim pledges his recognition and the found child becomes valid as his own, and his lineage becomes valid with whoever recognizes her, he can be called a biological parent. According to Imam Malik, 'unless he can prove and have justified reasons based on the Islamic Law, the validity of the lineage is not based on the recognition of whoever found the child. ${ }^{11}$

10 Abdul Rokhim, "Status Anak Laqit (Anak Temuan) Menurut Hukum Islam," Jurnal Ilmu Hukum Dalam Reflesi Hukum 18, no. 1 (2014), https:/ / ejournal.uksw.edu/refleksihukum/article/view/454.

${ }^{11}$ Ahmad Husni, Ahkam Syari'yah Fi Ahwalisy Syahsiyyah Ala Mazahibil Imam Abu Haniffah, (Kairo: Darul Qutub, 1960). 
Adoption affects guardianship and inheritance cases. The new parents become guardians of the child suppose the court determines so. Except for adopted daughters who are Muslims, the only person who has the right to be the marriage guardian is the biological parents or blood relatives. However, in the Compilation of Islamic Law (KHI), ${ }^{12}$ Adopting a child does not impact marital guardianship or the law on cognation. It only affects transferring the maintenance of power alone.

Previous research and this dissertation differ in that the former is still normative, while the latter focuses on narrative and sociological, philosophical, and juridical aspects to study the data. The academic problem is the status of the found child from the viewpoint of maqasid al shari'ah. Besides, to appreciate the authority of the Religious Courts according to Law number 3 of 2006 in the field of child adoption (laqith), maqasid al shari'ah is used as the theoretical framework.

Based on the findings, the difference between previous research and this dissertation lies in adopting a child after creating Law Number 3 of 2006 on Religious Courts. Therefore, all decisions on adopting a found child should harmonize with Law Number 3 of 2006 and the related regulations. Several decisions that have been in line with maqasid sharia have considered the benefits, and they and are based on the interests and rights of the children for their welfare.

12 "KHI is a summary of various legal opinions taken from various books of fiqh, to be processed, developed, and compiled in a single association used by judges as applied law (material law) in the religious court, in the form of Presidential Instruction No. 1 of 1991," 1991, http://www.percaindonesia.com/wpcontent/uploads/2013/12/KOMPILASI_HUKUM_ISLAM.pdf. 


\section{RESEARCH METHODS}

This normative legal study ${ }^{13}$ examines the Islamic Law related to adopting a child and the legal implications from the perspective of Law Number 3 of 2006. Meanwhile, the approach used to examine the problem is normative juridical. ${ }^{14}$ This is conducted by organizing data set for review and examination for the norms implicit in the statutory literature and decision documents about the legal provisions and consequences of adopting a found child.

The data are sourced and collected from literature studies from primary references in binding legal materials, especially laws and regulations on Indonesian child adoption and the legal implications based on Islamic and National Law. These include the Qur'an and Hadith, Law No. 7 of 1989 on Religious Courts, Law No. 3 of 2006 on amendments to Law No. 7 of 1989 on Religious Courts, which was last amended by Law No. 50 of 2009, several laws on child welfare, government regulations on the implementation of child adoption, and presidential instruction No. 1 of 1991 on the Compilation of Islamic Law. Secondary references relate to primary legal materials through books, journals, papers, textbooks, and expert opinions for Islamic Law courses.

The data collection technique used in this study is a literature review by reading, studying, taking notes, summarizing, and reviewing library materials related to the adoption of the findings. Furthermore, legal materials are organized through inventory and procedural identification of laws and regulations. Classification and systematization are then conducted so that the law harmonizes with the research problem. Still, normative legal research data study is run qualitatively and descriptively, which is a method academicians

${ }^{13}$ Abdul Kadir Muhammad, Hukum Dan Penelitian Hukum (Bandung: Citra Aditya Bakti, 2004), 52.

${ }^{14}$ Muhammad, 112. 
employ to reveal the knowledge or theory used in a study at a certain time.

In normative legal research, the processing of collected data is by systematizing written materials. Systematization is meant to classify written legal materials to facilitate the analysis and construction. ${ }^{15}$ The collected legal materials are discussed, examined, and grouped into certain sections to be transformed into data in the form of information. The analysis results of the materials are then interpreted using the method of (a) systematic, (b) grammatical, and (c) teleological interpretation. ${ }^{16}$

\section{DISCUSSION}

\section{Analysis of Maqashid Shari'ah on Found Child}

The Compilation of Islamic Law $(\mathrm{KHI})^{17}$ in Chapter 1 concerning the general provisions of letter ' $h$ ' states that 'an adopted child is a one whose responsibility for the daily care, education costs, and others shift from the biological to the adoptive parents based on court decisions.' Therefore, the process should go through a court decision procedure. The fundamental problem of a found child adopted by someone is the urgency associated with lineage, guardianship, and inheritance.

Considering the many abandoned children, nurturing, taking, and caring for laqith children is necessary. Furthermore, the Qur'an

15 Soerjono Soekanto and Sri Mamudji, Penelitian Hukum Normatif: Suatu Tinjauan Singkat (Jakarta: Rajawali, 2001), 251-52.

16 Jimly Asshiddiqie, Teori $\mathcal{E}$ Aliran Penafsiran Hukum Tata Negara, (Jakarta: Ind.Hill.Co, 1997), 17-18.

17 "KHI is a summary of various legal opinions taken from various books of fiqh, to be processed, developed, and compiled in a single association used by judges as applied law (material law) in the religious court, in the form of Presidential Instruction No. 1 of 1991." 
Surah Al-Maidah $32^{18}$ states that 'whoever kills humans for no reason kills or causes damage to the earth's surface and also seems to kill all humans, and whoever preserves the lives of other humans maintains human life as a whole. The elements that should be maintained and realized are religion, soul, mind, lineage, property, and human rights (dignity) in maqasid al shari'ah. The benefits are realized when it maintains the main six tenets.

To establish the law based on the purpose of Islamic Law and attract benefits and reject harm, determination happens through maqasid al shari'ah. There are three levels of maslahah. ${ }^{19}$ First, maslahah daruriah is a benefit that makes life chaotic and eradicates it in case it is not fulfilled. Second, maslahah hajiat, that impacts damage. Third, maslahah tahsiniyat, which provides more value, maximizes goodness, and does not exert impact, suppose it is not fulfilled.

The theory of benefit in Maqasid has opened a perspective to the position of a found child whose parents and origin are unknown. Therefore, raising, nurturing, and educating her to give meaning to survival becomes a wise goal in the form of benefit.

The application of benefits in maqashid sharia while adopting daughters uses maqasid dauriyah. It includes six objectives, namely, ${ }^{20} 1$ ) Hifz Din to protect the child's religion. This is because religion is fundamental for the future of a found child and humans. 2) Hifz Nafs is to protect lives and their rights, and the abuse for a found child. Islamic Law values a person's life. It protects a found child whose condition requires being saved from the danger of death or extinction in case no rescue efforts are made. 3) Hifz "Aqli is to maintain mind, including the right to education, think, and receive

\footnotetext{
${ }^{18}$ Depag Islam, Al-Qur'an Dan Terjemahnya (Depag RI, 2012).

${ }_{19}$ Abu Ishaq Al-Syatibi, Al-Muwafaqat Fi Ushuli al-Syariah (Beirut: Al-Kotob Al-Ilmiyah, 2004).

${ }^{20}$ Ahmad Sarwat, Maqashid Syariah (Jakarta: Rumah Fiqih Publishing, 2019), 25.
} 
guidance to form a good mind for the found child. Therefore, she will have an intelligent mind in the future and become the next generation that is able to and perfectly thinks. The mind is also protected from any evil that can wreak havoc. Besides, Hifz "Aqli is to provide education to the found child. 4) Hifz Nasl is to maintain lineage. The basis of adopting a found child (laqith) is to protect her from unwanted things, besides maintaining and educating her for the future, although the parents are unknown. 5) Hifz Maal is to maintain the property rights of the found child. Her property is the responsibility of whoever finds or maintains her and can be used only for thebenefit. 6) Hifz al-Ard is the protection of honor in the form of dignity and/human rights. The core problem in human rights is to protect a person from threats and obstacles from other parties and to protect human existence from their damage.

According to academicians, the three forms of benefits are equivalent to primary, secondary, and tertiary needs. The basic human rights in Islam for adults and children guarantee living, reproducing, and getting education and a decent life. In Islamic history, Baitul Maal is one of the oldest institutions that guarantee the lives of the citizens of Medina from starvation. Since the beginning, Zakat and sadaqah institutions have existed, and the distribution o is managed by 'amil. This implies the wisdom that the task should be handled professionally. Besides individual zakat, there is also baitul maal. The poor get help here in case they are neglected by their relatives (dzul qurba).

The Prophet's Mosque is another institution. In ancient times, this mosque was a place of worship and also had a social function. In it, there are ahlus shufah or people who live in mosques because they 
do not have another place. ${ }^{21}$. Therefore, since the beginning of Islamic history, the guarantee for basic needs has been felt.

Adopting a laqith child should comply with the provisions contained in Law No. 3 of 2006 in amending Law No. 7 of 1989 on Religious Courts on the basis and purpose of the child. This abolishes the previous regulation on adopting a child to benefit the adoptive parents. Therefore, the problem of adopting a child while prioritizing the value of maqasid al shari'ah looks at human benefits in a personal and worldly manner and also pays full attention to social and ukhrowi (afterlife) challenges that provide solutions to human rights, including those who have children's rights that need protection. This harmonizes with the word of God in Surah Al-Isra' verse 70 as follows ; ${ }^{22}$

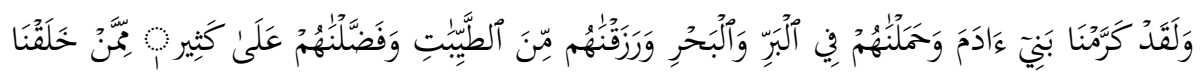



'And We have honored the Children of Adam. We carried them in the land and the sea, and We have given them as sustenance of the permissible things, and We have made them excel by an appropriate excellence over most of those whom We have created.'

From the verse, Allah elevates humans and purifies them. Therefore, human rights essentially protect a person from interference, obstacles, and challenges from outside parties and the damage they cause.

${ }^{21}$ Muhammad Utsman Al-Khasyt, "Ahlus Shufah Artinya Penghuni Serambi, Atau Orang Yang Tidur Di Serambi Masjid Nabawi Dalam Jumlah Yang Sangat Banyak Waktu Era Rasulullah.," in Fikih Wanita Empat Madzhab: Ijtihad Fikih Kontemporer, Terj. Abu Nafis (Bandung: Ahsan Publishing, 2010), 76-78.

${ }^{22}$ Islam, Al-Qur'an Dan Terjemahnya. 


\section{The Authority of the Religious Courts in Laqith and Adopted Children}

Based on Law No. 3 of 2006 Article 44 letter a, number 20, the religious court has the authority to determine the origin and adoption of a child based on Islamic Law (Lex specialist). This, in turn, is authorized to settle special cases, including adopting a child between Muslims. ${ }^{23}$

There are no texts from the Qur'an or hadith that can be used as references in the guardianship of marriage by multaqit's adoptive father. Neither is there any from the product of state regulations that dictate found child marriage guardianship. However, the jurisprudence states several judges' decisions that can be consulted to determine how valid the adoptive parents are for the marriage guardianship status for the laqith child.

The judge has the right to determine whether the marriage guardian conducted by the adoptive father for the marriage of his laqith daughter is valid. When the guardianship was conducted by the adoptive father, the application for the validity of the marriage was found most of the time. This study supports Abu Qudamah, who states that 'the guardianship of laqith child can be conducted by the adoptive father. ${ }^{24}$ Furthermore, this research did not find cases or disputes in marriage concerning the guardianship of laqit child. However, it found several guardianships of adopted children legalized or not legalized by the Religious Court with different considerations.

${ }^{23}$ Mukti Arto, "Asas Personalitas Islam Adalah Hukum Dasar Mengenai Keseluruhan Pribadi Seseorang Yang Berkaita Dengan Agama Islam, Berdasarkan Asumsi Bahwa Orang Islam Adalah Subyek Dari Hukum Islam.," in Penemuan Hukum Islam Demi Mewujudkan Keadilan, 2nd ed. (Yogyakarta: Pustaka Pelajar, 2018), 279.

${ }^{24}$ Abu Qudamah, Al-Mughni Wa al-Syarh al-Kabir, Dar al-Kutub al-'Arabi., juz VI. (Darul Qutub, n.d.), 386. 
A specific case concerning the adoptive father's marriage guardianship of a laqith child has not been found. Suppose such occurs, it takes the "courage" of the panel of judges to determine the validity. However, in some cases, the judges decide on the stipulation of marriage itsbat against a woman guarded by the adoptive father because the parents and relatives (the lineage guardian) are not Muslim. According to academicians, this can be a jurisprudence to validate a marriage guardian by an adoptive father against his laqith child. This is because a convert and laqith child are similar when they do not have a lineage guardian for the marriage contract.

Adopted children from the laqith and orphans differ from children with biological parents. Orphans have kinship relatives and mutual inheritance relationships between them. For example, between orphans and their father's biological grandfather, although their adoptive parents care for them in their daily life. Meanwhile, female orphans can obtain guardianship from their lineage guardians (their father's grandfather or brother). However, the laqith adopted children do not own such a relationship, although based on KHI, they are entitled to a will (obligatory). Therefore, in determining inheritance issues on the laqith child, the legal case should also be similar to other adopted children first. This is because they have the same inheritance law despite being different.

No positive law relates to mandatory wills as regulated in the history of Indonesian legislation, except the Compilation of Islamic Law Article 209, which states that 'adopted children are entitled to a share of $1 / 3$ of the total inheritance from their adoptive parents.' The panel of judges at the Religious Courts is the most authorized party in resolving civil issues between Muslims, including inheritance law. In adopted child rights, the judges also have the right to determine 
the amount of the mandatory will to the child and determine how many shares the heirs will obtain.

Based on the Jurisprudence of the Supreme Court's Decisions 368K/AG/1995 and 51/AG/1999, judges of the High Court have the right to ensure that non-Muslim biological children get a share of the inheritance from their parents. As a comparison to the mandatory will which should also be given to laqith adopted children, the following are the decisions of the Religious Court for non-Muslim adopted children.

A judge grants a mandatory will to a child based on the following considerations; 1) the child in question is actually the adopted child of the testator according to evidence or witnesses. 2) the granting of a mandatory will does not exceed 1/3 of the assets the testator inherits. 3) The amount of the mandatory will should consider the rights of other heirs.

The Religious Court is an autonomous institution that examines and adjudicates civil cases among Muslims. The Religious Court stands next to the District Court. It does not violate the philosophy of Pancasila with the precept of the One Supreme Godhead, which suggests the existence of religion as the basis for understanding the next precepts. ${ }^{25}$

The Religious Court is also authorized to decide cases related to the status of a found child with the same rights as orphans since they are entitled to get guardianship of their property. A question arises, how can a laqith child get wealth? Wasn't she found in the middle of the road, with nothing but attached clothes?

A laqith child only gets a lot of wealth in case she gets an inheritance (or through a mandatory will scheme) from the adoptive parents or through other means, including finding items of great

${ }^{25}$ Gunawan Ahmad and Muammar Ramadhan, Menggagas Hukum Progressif Indonesia (Yogyakarta: Pustaka Pelajar, 2006), 259. 
value. The most common cases have an orphan get a large amount of inheritance. The mother or uncle becomes the guardian of the property.

Based on the applicable regulations, an adopted, a laqith, and a child whose parents can abandon, are entitled to a mandatory will. Suppose the adoptive parents of a laqith child left when young. She will not return to the original family or one related by blood unless she gets property from parents' inheritance, and then it is passed on to one of the relatives.

Like the adoptive father's marriage guardian, the specific case of a laqith child who gets a mandatory inheritance is not found in several guardianship cases tried in the Religious Court. Although the Religious Court is the most authorized institution in dealing with civil matters involving Muslims, similar cases can be compared, including appointing guardianship over the property of an orphan.

Apart from guardianship in property matters, there is the 'right of custody' in positive law granted to a person related to the care of a minor child. The syar' $i$ term is hadhonah, or the right to care for orphans. In terms of positive law, hadhonah (maintenance) rights differ from nurturing and guardianship. A child (Fulan) can be adopted by A but still has several adoptive parents helping daily, such as B. Furthermore, if she has property, the right of guardianship does not necessarily fall on to A or B. Still, it can go to C, who is more capable of taking legal action. The application for guardianship rights is usually made by the biological mother of the child to make transactions on the late husband's inheritance in cases submitted to the religious court. For this, she can play a dual role as the party with the right of maintenance and still becomes the guardian of the property of the biological child. In terms of figh, she is waliy an nafs and waliy al maal. 
Regarding the guardianship of a laqith child, it is a matter of justice for adoptive parents to raise a child of unknown origin. The above are considerations for reference for judges in deciding cases, including the marriage for a laqith daughter. Since the Law No. 1 of 1974 was issued, Muslim couples marry at the Religious Affairs Office (KUA), and non-Muslims use the Civil Registry Office (KCS) ${ }^{26}$. This distinction follows the provisions of Muslim marriages that differ from other religions, including terms and pillars that cannot be equated. In Islamic marriages, conditions are that the bride and groom be of the same religion, have permission from a guardian, and others. Furthermore, pillars of the contract and the dowry should be spoken orally before the guardian accompanied by the witnesses. In they are fulfilled, the marriage is validated. This does not apply to other religions. Moreover, being that Islam is the Indonesian majority religion, it is important to authorize the Ministry of Religion to decide marriages under Islamic Law on munakahat. Therefore, according to Indonesian Law, marriage is only valid in case it is conducted according to the laws of each religion and belief. ${ }^{27}$

\section{Reviewing the Decision on the Adoption of Found Child (laqith) in the Religious Court after Law No. 3 of 2006 on the Religious Court}

This case applies for Marriage Isbat at the Pematang Siantar Religious Court in 2013, after Law Number 3 of 2006 on Amendments to Law Number 7 of 1989 concerning Religious Court on March 20, 2006, was enacted.

The applicant was married in 1997, and has 3 children. Still, the marriage was not registered at the Religious Affairs Office because it

26 M. Amin Suma, Kawin Beda Agama Di Indonesia: Telaah Syariah Dan Qanuniah (Tangerang: Lentera, 2015), 27.

27 Warkum Sumitro, Legislasi Hukum Islam Transformatif (Malang: Setara Press, 2015), 60. 
was conducted by the village head. At the Religious Court trials, the applicant presented two witnesses who stated that his marriage happened with a dowry of a set of prayer tools and with the guardian of the adoptive father of the bride since a lineage guardian who is Muslim was lacking as the bride is a convert.

The panel of judges at the Pematang Siantar Religious Court basically granted the applicant's request by stipulating that his marriage carried out in 1997 with the adoptive father as guardian was declared valid. This is because all lineage guardians of the female are not Muslims, the origin of the female convert is equated with laqith, and the lineage guardian with the right to marry is unknown.

Based on this decision that granted the application for marriage itsbat with the guardian of the adoptive father, it is understood that the recognition of a laqith child as his own child is acceptable in Islamic Law because the guardian in the marriage isbat is a lineage guardian. In case it is not understood as a lineage guardian, the marriage guardian cannot or does not marry off his adopted daughter (laqith). Since the Pematang Siantar's decision applies considerations supported by Maqasid sharia reasoning, the laqith children have a place in Islamic Law.

This case originates from the Lubuk Linggau religious court in the inheritance case. It contains the following: a husband has no children for years then adopts a child. Furthermore, his wife died and left a lot of property which he and his adopted child managed. The late wife has three siblings entitled to the inheritance. For this case, the Lubuk Linggau Religious Court decided that the heirs were the husband, sister ( 1 person), brothers ( 2 people), and adopted daughter of the late wife. The number of shares for heirs is determined as follows: husband, first brother, sister, second brother, 
and adopted child have 5/12, 2/12, 1/12, 2/12, and 2/12, respectively.

Based on this, the laqith adopted child of the testator has the right to receive an inheritance from the determination rights, and the division has met a sense of justice. Furthermore, the decision has considered the juridical, sociological, and philosophical sides that harmonize with Maqasid sharia. Hence the adopted child becomes the heir and gets the inheritance share.

\section{CONCLUSION}

Child adoption cases are under the authority of the Religious Court after the creation of Law no. 3 of 2006. Therefore, all decisions should harmonize with the provisions in Law Number 3 of 2006 and related regulations. The adoption of a found child (laqith) aims to protect, maintain, and prevent harm to enhance survival and benefit welfare. The main basis for adoption is to save one from unwanted things, apart from maintenance and education for the future. Therefore, the lineage can be given to adoptive parents through recognition by iqrar nasab and maqasid al sharia dharuriyah reasoning with the aim of benefit to protect and maintain religion, soul, mind, texts, descendants, and assets. Furthermore, because being already a nashab child, the adoptive parents have guardianship and inheritance rights.

Adopting a laqith child by the Religious Court after Law no. 3 of 2006 was enacted to develop the Indonesian Islamic Law is relevant. It ensures that all matters relating to the adoption harmonize with the existing provisions in Law no. 3 of 2006 on Amendments to Law no. 7 of 1989 about the Religious Court. Applying the law to settle cases about the adoption of a found child needs to consider the understanding of the law scientifically, which is built on the principles, rules, and norms. It should also consider the legal rules 
through juridical, sociological, and philosophical logic structured through a maqasid al sharia approach as the basis for its reasoning in the decision and enriches the repertoire of the Indonesian legal jurisprudence. Therefore, as a product of the Religious Court, the decision realizes the law in everyday life in society, especially that adopting a found child has a place in developing the Indonesian Islamic Law.

Since academicians can interact directly with the subject and feel the real-life between adoptive parents and the found child on the theme of laqith child, studies on child adoption are very good in case they are conducted using field study methods. In the future, studies can be conducted with various methodologies to obtain in-depth results because they are based on interviews, observations, and the sampling of subjects.

\section{DAFTAR PUSTAKA}

Ahmad, Gunawan, and Muammar Ramadhan. Menggagas Hukum Progressif Indonesia. Yogyakarta: Pustaka Pelajar, 2006.

Al-Khasyt, Muhammad Utsman. "Ahlus Shufah Artinya Penghuni Serambi, Atau Orang Yang Tidur Di Serambi Masjid Nabawi Dalam Jumlah Yang Sangat Banyak Waktu Era Rasulullah." In Fikih Wanita Empat Madzhab: Ijtihad Fikih Kontemporer, Terj. Abu Nafis. Bandung: Ahsan Publishing, 2010.

Al-Syatibi, Abu Ishaq. Al-Muwafaqat Fi Ushuli al-Syariah. Beirut: AlKotob Al-Ilmiyah, 2004.

Arto, Mukti. “Asas Personalitas Islam Adalah Hukum Dasar Mengenai Keseluruhan Pribadi Seseorang Yang Berkaita Dengan Agama Islam, Berdasarkan Asumsi Bahwa Orang Islam Adalah Subyek Dari Hukum Islam." In Penemuan Hukum Islam Demi Mewujudkan Keadilan, 2nd ed. Yogyakarta: Pustaka Pelajar, 2018. 
The Adoption of Found Child According to Islamic Law...

Asshiddiqie, Jimly. Teori \& Aliran Penafsiran Hukum Tata Negara, Jakarta: Ind.Hill.Co, 1997.

Azis, Dahlan Abdul. Ensiklopedi Islam. Jakarta: PT Ichtiar Baru Van Hoeve, 1980.

Ghandûr, Ahmad al-. Al-Akhwâl al-Syakhshiyah Fi al-Tasyri al-Islâmî. Beirut: Maktabah al-Falah, 2006.

Husni, Ahmad. Ahkam Syari'yah Fi Ahwalisy Syahsiyyah Ala Mazahibil Imam Abu Haniffah, Kairo: Darul Qutub, 1960.

Islam, Depag. Al-Qur'an Dan Terjemahnya. Depag RI, 2012.

Jauziyah, Ibn al-Qayyim al-. I'lām al-Muwaqqi'in. 3. Kairo: Daarul AlKutub Al-Hadis, 1969.

Ka'bah, Rifyal. “'Pengangkatan Anak Dalam UU No. 3 Tahun 2006 Tentang Perubahan Atas UU No. 7 Tahun 1989 Tentang Peradilan Agama Dan Akibat Hukumnya' Makalah Dikembangkan Dari Diskusi Berkala III Di Bidang Pencatatan Sipil Antara Para Ahli Hukum Islam Dan Hukum Sekuler," 2006.

“KHI Adalah Rangkuman Dari Berbagai Pendapat Hukum Yang Diambil Dari Berbagai Kitab Fikih, Untuk Diolah Dan Dikembangkan Serta Dihimpun Dalam Satu Himpunan Yang Dipergunakan Oleh Hakim Sebagai Hukum Terapan ( Hukum Materiil ) Pada Peradilan Agama, Yang Berbentuk INPRES Nomor 1 Tahun 1991," 1991. http:/ / www.percaindonesia.com/wpcontent/uploads/2013/12/KOMPILASI_HUKUM_ISLAM.pd f.

Muhammad, Abdul Kadir. Hukum Dan Penelitian Hukum. Bandung: Citra Aditya Bakti, 2004.

Mukri, Moh. Paradigma Maslahah Dalam Pemikiran Al Gahzali Sebuah Studi Aplikasi Dan Implikasi Terhadap Hukum Islam Kontemporer. Yogyakarta: Pesantren Nawasea Press, 2009. 
Praja, Juhaya S. Teori Hukum Dan Aplikasinya. Bandung: Pustaka Setia, 1994.

Priyambodo. "Mensos: Masih Banyak Kasus Anak Terlantar." News. Antara News, 2015. https://www.antaranews.com/berita/496359/mensosmasih-banyak-kasus-anak-terlantar.

Qardhawi, Yusuf. Fikih Maqasid Syari'ah. Jakarta: Pustaka Al-Kautsar, 2007.

Qudamah, Abu. Al-Mughni Wa al-Syarh al-Kabir, Dar al-Kutub al'Arabi. juz VI. Darul Qutub, n.d.

Rokhim, Abdul. "Status Anak Laqit (Anak Temuan) Menurut Hukum Islam." Jurnal Ilmu Hukum Dalam Reflesi Hukum 18, no. 1 https:// ejournal.uksw.edu/refleksihukum/article/view/454.

Sarwat, Ahmad. Maqashid Syariah. Jakarta: Rumah Fiqih Publishing, 2019.

Soekanto, Soerjono, and Sri Mamudji. Penelitian Hukum Normatif: Suatu Tinjauan Singkat. Jakarta: Rajawali, 2001.

Suma, M. Amin. Kawin Beda Agama Di Indonesia: Telaah Syariah Dan Qanuniah. Tangerang: Lentera, 2015.

Sumitro, Warkum. Legislasi Hukum Islam Transformatif. Malang: Setara Press, 2015.

Zuhaili, Wahbah. Ushul Figh Islamy. 2. Damaskus: Dar al Fikr, 1986. 